DOI: 10.1515/ausp-2015-0008

\title{
Intercultural Passages in Ottó Tolnai's Textual Universe
}

\author{
Julianna ISPÁNOVICS CSAPÓ \\ University of Novi Sad (Serbia), Faculty of Philosophy \\ Department of Hungarian Studies \\ csapo@eunet.rs
}

\begin{abstract}
The literary palette of Tolnai's textual universe within the Hungarian literature from Vojvodina is based, among others, upon the intertwining of various cultural entities. The social and cultural spaces of "Big Yugoslavia," the phenomena, figures, and works of the European-oriented Yugoslav and ethnic culture (literature, painting, book publishing, theatre, sports, etc.), the mentalities of the migrant worker's life, the legends of the Tito cult embed the narrative procedures of particular texts by Tolnai into a rich culture-historical context. Similarly to the model of Valery's Mediterranean, the narrator's Janus-faced Yugoslavia simultaneously generates concrete and utopian spaces, folding upon one another. Above the micro spaces (towns, houses, flats) evolving along the traces of reality, there float the Proustian concepts of scent and colour of the Adriatic sea (salt, azure, mimosa, lavender, laurel). The nostalgia towards the lost Eden rises high and waves about the "grand form" of Big Yugoslavia, the related space of which is the Monarchy. The counterpoints of the grand forms are "the small, void forms," provinces, regions (Vojvodina, North Bačka) and the micro spaces coded into them. The text analyses of the paper examine the intercultural motions and identityforming culture-historical elements of the outlined space system.
\end{abstract}

Keywords: textual universe, culture history, intercultural passage, identity, Ottó Tolnai

\section{Forming spatial relations in Ottó Tolnai's prose}

In the panopticon of Tolnai's texts "the grand forms are always counterpointed, from the outset, by small, void forms, though these are well-contoured territories, regions, places, small communities like Fáj — —such as Vojvodina or North Bačka,

1 Fáj is a hamlet in Hungary, in Borsod-Abaúj-Zemplén county, in the micro-region of Encs, 50 kilometres northeast from Miskolc. The settlement was first mentioned in 1243 as the Fáy family's estate. Currently it has 372 inhabitants. (personal remark, http://foldhivatalok.geod.hu/ telepules.php?page=2741) 
Lana in South Tyrol, Frisia [...], Szatymaz, Kičevo and Aporka or, for example, Járás and Vértó [...]" (Tolnai 2011 (2007), 297).²

The space coordinates of textual motions are diverse. In the Lovers of Pompeii [Pompeji szerelmesek] the narratorial gaze is narrowed, it turns from the large space into the direction of smaller, seemingly less significant dimensions: Big Yugoslavia, Small Yugoslavia, Serbia, Vojvodina, Bačka, North Bačka or Hungary, Budapest, Lónyay Street, Pilisborosjenő.

In Grenadírmars, the "strictly closed unity," homogeneity of the Monarchy and Big Yugoslavia, of the Adriatic Sea and Bačka, culminates in one single everlasting moment, "When in the midst of the creaking of the rails-typical of the Monarchy-the train stopped" (Tolnai 2011 (2008), 290).

The space treatment of the "stained water prose" uses the technique of reflecting. The coordinates of two parallel worlds folding onto each other are outlined, the infinity of which (the immanent macro and micro spaces) become adjacent again and again during the time travels of the narrator and its alter egos, during their "crab-like regress." The twin points emerging from the space, the lighthouses of the sea with light strips and the grain silos of the Great Plain, the Adriatic Sea and the Pannonian landscape, the Pannonian Sea are stressed interfaces.

The flavour associations completing the sight reconcile earlier already this specific, twofold, temporal and spatial sea experience of Tolnai's texts. The gastronomic memory of Bačka from the Monarchy is projected onto the world of the Adriatic: "pretending to be dumb, I was listening to désiré's the new thesis / that a poet has to eat a lot of sweets / a lot of bonbons and bombs with rum / he says he adores me by the oversalted Adriatic ink soup / suffocating in small confectioneries in big cream cakes" (Tolnai 2010 (1992), 81).

The relation between sugar and salt, sweet and bitter emerges in its entirety in the textual universe of Tolnai's "stained water prose." The twin towers of brine pits from North Dalmatia and Istria are projected onto the continental (Vojvodinean) sugar factories of Big Yugoslavia. Ottó Bocskay, the mythical alter ego of the narrator is the accountant of the sugar factory in Senta. Ottó, magnified with the devices of magical realism, may become a member of the Novi Sad Writers' Community, of the Vojvodinean Writers' Association, and moreover, even of the Yugoslav Writers' Association if his great work in progress, "his big sweet book," is ready sometime. Ottó's amazing abilities revaluate even the significance of the brine pits. Besides the vision of the "sweet book" it is essential to engage "the salty book" as well:

Then another picture: Ottó is walking around the brine pits [...] it would not have taken one or two years, and Ottó would have connected the sugar factories of Vojvodina with the Dalmatian brine pits, launching a never

2 Quotations from Hungarian literary works and specialist literature were translated by Katalin Süge. 
witnessed barter trade among them-I forgot to mention that the sugar factory in Senta (or the milk factory, I do not know exactly) had a holiday villa on Krk Island. Each small town in Vojvodina had a holiday villa near the Adriatic; what is more, larger companies had their own separately [...]. (Tolnai 2010, 16)

In this way Ottó, “our great, bitter writer,” will be the descendant of Károly Szirmai, lawyer of the sugar factory in Vrbas.

Besides the traces of World War II (the monument of the battle in Batina) and the bridgeheads of the modern Balkan wars (the Maslenica bridge in Croatia, the Novi Sad bridges bombed by NATO), the map of the incessantly disintegrating and transforming Big Yugoslavia (Csányi 2007) is enriched by the various micro spaces, from the time of the Monarchy, of Bačka. The hometown, Stara Kanjiža in Bačka that "by now lives mainly in my imagination" (Tolnai 2010, 9) unfolds its virtual, mythical spaces in accordance with the movements of the alter ego: "[...] I saw Ottó appearing on the promenade, by the Tisza, in the Tükörfürdő, in the Nylon restaurant, on the promenades of the Népkert, around the sculpture of the gypsy girl exchanging pleasantries in the group of the miracle bath [...]" (Tolnai 2010, 12). The intimate place of the narrator limited to the minimum is the tower room of Homokvár by the coast of the Vértó, lined with papers, paintings, culture and art.

The heterogeneous continental micro spaces of Tolnai's text are completed with the colours of the Adriatic Sea: the azure of the lavender, tamarisk, mountain laurel, bogumil and saffron. The colour of the sea cannot be defined exactly. This mystery has a tradition in the history of literature, and this infiltrates in the Tolnai opus as well. In the Lovers of Pompeii Attila József and Lajos Nagy

[...] argued about the colour of the sea. Attila József claimed that the colour of the sea is: green; Lajos Nagy said that the colour of the sea is: blue. Finally, Attila József has given up his position, saying: it is blue indeed:but in another way. Notwithstanding, he could have safely clung to his opinion, namely that the sea is: green. But in another way, of course. (Tolnai 2011 (2007), 115)

The definition of colour within the "stained water prose" is not contingent; it rests on scientific basis. The reference of Tolnai's text is dr. Béla Mauritz's "specific red leather spine volume" entitled The Earth and the Sea [A föld és a tenger]. In the third volume of the series The World of Nature [A természet világa] the following definition can be read:

[...] we can define the colour of the sea as blue and through that turning into green. If the standard white sheet with a diameter of $0.5 \mathrm{~m}$ is floated 
out, it first looks green, then as it sinks deeper and deeper, it turns into more and more bluish, and finally it entirely disappears from the observer's view. [...] There are still a lot of deficiencies and arguable parts in the explanation of the colour of the water on a strict physical basis. The prospective researches still need to fill a wide gap. In some places there also appear some extraordinary colours of the sea. The sailors call this kind of water 'stained' water. (Tolnai 2010, 77-78)

For Tolnai, the (sea) colour is a metaphysical category (Acsai 2004). Its nature and quality cannot be precisely defined, not even when approached from the direction of science. The refractions of light, the illusions of the Adriatic's stained water are diverse, they cannot be precisely described, they are constantly changing as much as we regard them as the reflections of parallel worlds gleaming in the waving of the "stained water prose," and not merely of the Balkan (Ladányi 2004).

The relations between literary spaces and real spaces in Ottó Tolnai's texts are variegated. The most typical is the case of a transformed relation, of remodeling or synthesis of various spaces. There often occur synthesized spatial forms, special forms when "within the text, two or more spaces are synthesized to a new, third space" (Reuschel-Hurni 2011, 296). Applying space shifting, when "an existing place is shifted to a new location, in a new geographical context" is also characteristic of Tolnai's prose (ibid.).

\section{Spaces and cultures}

The multilingual cultures (of the Monarchy, Vojvodina, Yugoslavia, Bačka) appearing in the spaces of Tolnai's prose get condensed into short story-like text parts, fragments generating each other, organized around figures and artworks moving in the textual spaces.

The narrator's "chosen terrain” (Tolnai 2011 (2008)), the Monarchy and Big Yugoslavia, the Adriatic and Bačka "form a strictly closed unit." The corn mountains of Bačka shining like gold, the bottom of the Pannonian Sea containing natron, the lapwings swarming like seagulls, the "Monarchy-yellow" and the "Monarchy-yellow buildings (railway stations, courts, high schools)" (Tolnai 1992, 12) melt with the mimosa fragrance of Big Yugoslavia, with the colour and fragrance cavalcade of the traditional ceremony of mimosa picking held in Hercegnovi, because "the yellow effect has been placed next to the azure" (Tolnai 2011 (2007), 298).

The belonging together of the Austro-Hungarian Monarchy and Big Yugoslavia is confirmed by the in-between position and living space of the amphibious figures. 
All I know about Krstonošić, Éva's former boss, is that he no longer participates in rally racings in Monte Carlo, he has not entered for the route of Paris-Dakar for a long time, he roams with a scooter the streets with worse and worse pavements in Novi Sad, and spends more and more time in Ljubljana and Prague, where he moved his studio and also his office; he was a typical middle-class Monarchy figure, he kept the photo of his mother playing tennis with Miklós Horthy, or at least they can be seen together with tennis rackets in their hands. (Tolnai 2010,11)

One of the famous Bačka pharmacists of the Monarchy times, the local poet, Aurél Stadler "spent a part of all of his summer holidays by the Adriatic, in Dubrovnik, the so called folk-natural, close-to-the-ground poems of his about Palić, Ludas, and Hajdukovo alternating on a regular basis with the mondaine Adriatic poems" (Tolnai 2004, 119). The "days of glory" of Big Yugoslavia are entwined with the intermediary states of the migrant worker existence: "since the musicians in Vojvodina used-better said, not just used, it was obligatory for them-to spend the summer by the sea, they played music in hotels or on pleasure boats, thereafter all of them to continue in Germany [...]" (Tolnai 2004, 125). The position of the above figures may even be connected with the twofold trend of Hungarian literature and culture in Vojvodina, with the tendencies, with their eternal conflicts, formulated in the spirit of "odi et amo," of (ethnic, national) preservation, on the one hand, and of innovation, longing to leave, being constantly on the way (modernism, western patterns), on the other. Bačka and the sea are also basic motifs in Ervin Sinkó's early poems, in Kornél Szenteleky's novels and poems, as well as in the art of the Symposion generation.

Yugoslavia is, on the one hand, "a positive grand form, like the Monarchy" (Tolnai 2010 (1997), 80). On the other, its volatility is conspicuous, since, quite like Valéry's Mediterranean, it is simultaneously concrete and utopian (Tolnai 2011 (2007), 100). Its spaces are retiform, abundant in passages; it is a heterogeneous structure in which "All units are primarily the net of solidarities and the affinity of mentalities" (Daniel 1996). Thirdly, it is irony itself taking shape: “...one of his sons was given the name Yugoslav, the other one Tito, although his BelgianCongolese wife had no idea of what Yugoslavia meant and who Tito was. I said that if things went on like that, the poor woman would give birth to all the republicans, the entire Central Committee" (Tolnai 2011 (2007), 101).

The source of "manifestation" of Big Yugoslavia is private mythology. The passages of the Tolnai opus draw the metamorphosis of the narrator, the cases and stages of its turning into space, by the use of biography, biblical references, metaphor, sensual associations and metonymy. We become witnesses of the espacement of the body melting into space, into the sea (water). The halts of the process are the biography ("After all, the so-called Big Yugoslavia was identical 
with my life. They coincided [...] I had a thousand and one small intimate places all over the country." (Tolnai 2011, 180), certain stages of it, as well as the emotional states of the subject:

He remembered the first time he sank, he precisely recognized the water of the Danube, the gentle, yet so essential differences in quality between the Palić Lake, the Tisza and the Adriatic; in the first one there was his childhood, in the other his manhood, in the third his present (so much so since the Kis-Palics (Small-Palić) is called Vértó), and in the fourth his dreams, or maybe he could say, his utopia. (Tolnai 2011 (2007), 257)

The body "taken" from the surrounding material/space is present everywhere:

[...] this is the background against which insignificant things are revealed; North Bačka, Vojvodina, Big Yugoslavia, the Balkan Peninsula, the Adriatic as far as Trieste, Duino [...] Venice are nothing else, but my body, since everywhere some grain of dust, mud, shit, azure stuck on me; I was taken out from this and I do not associate things but reveal my own wounds [...] (Tolnai 2011, 286);

some of its parts can be precisely localized: “[...] Indeed, a part of me lives on the Adriatic by now. It floats in my memories between the intensely shining Split and the four islands, Hvar, Brač, Korčula and Šolta” (Tolnai 2010, 25). The separation of part from the whole, the metonymical representation of the narrator pave the way for the azure game of the "stained water prose": "I was still staring at the beautiful blue vase. At my blue reflected face. At the lake reflected as the sea." (Tolnai 2010 (1987), 271)

The hydrography, the rill system of the small and big world of the Tolnai type textual corpus is not confined to the problematization of the sea. The narrator's spaces are abundant in water: "I was born in a river, in the Tisza, in Stara Kanjiža, I live beside the Palić Lake-and all my life I have been preaching about a sea, the Adriatic" (Tolnai 2011 (2008), 345). As the lost, magical paradise, as the source of light (Daniel 1996), the appearance of the Mediterranean in central position is not unusual; it gains its function by fitting into the hydrography of the variable space/map. In footnote number 8 of Grenadírmars, the definition of János Apáczay Csere's lexicon (Hungarian Encyclopaedia) displays the sea as a magical, omnipresent element: "1. The water is sea or waters that have their sources in it. 2. The sea has external or internal [...] bosoms and streams." The magical hydrography of Tolnai's texts is based on similar principles. Essential elements are the lake appearing as the leftover of the sea (the Balaton, the Palić Lake, the narrator's "corn pie like" being [Tolnai 1994, 153]), the river flowing 
into the sea, and last but not least, the miracle, when the rivers of memories flow backwards. The state of "looking at the stained water" points back to the sight of the mayfly of the Tisza in July: "the concentration of the nuptials, fertilisation and death in this single moment shows us the complete model of existence" (Tolnai $2007,71)$. It points back to the water of the memories, which is the "mythical site of the author's childhood, the fluent, absolute chlorophyll” (Mikola 2012, 414). It refers back to the erotic relation with the Tisza:

among the red branched willow-bushes I totter down to the Tisza, often sinking into mire up to my ankles, especially in spring, and at this time of autumn I love to crouch near its steaming mass, while on the other bank I catch sight of a familiar, statue-like fisherman in his flat-boat, as if I would shamelessly crouch, lean over, have recourse to an uncovered sweet female body. In fact it is about re-positioning into the angle of the childhood. I dip my hand. I put my hands between the legs of the Tisza. I'm here, I say. And I wash my face [...]. (Tolnai 2010, 151)

"Since it is by no means incidental where the Tisza flows into the Adriatic" (Tolnai 2010, 119), because the Tisza flows into the sea on the ink-pencilled, magical, torn little Monarchy-map of childhood.

From time to time, the space built into the perishable body becomes objectified; the collapsed political, cultural space turns into the symbol of the grand form:

Empty, partly finished, storied alpine houses, all the money earned as a migrant worker being spent on them. They wanted houses our chiefs in Germany had. But everywhere only the kitchen was used. The whole Yugoslavia was full of houses like this. Throughout the past ten years, most of them were destroyed with some breathtaking method. (Tolnai 2011 (2007), 60)

\section{Text forming procedures}

The narrative units of Ottó Tolnai's texts are culture-historical elements. They form the base of the series of events, of the story. The dynamic alternation of the narrative units is provided by the omnipresent narrator's motions, his chain-like, inserted or parallel space shifts, as well as by the formation and movement of its various alter egos. The identity shaping, spatially embedded stories of Tolnai's prose get shape in the course of syntactic and textual processes that resort to devices such as reduction, strength and extension, compression, fragmentation, metaphoricity, symbolization and irony (Thomka 1986). Short stories, novellas, "little stories and fragments within the short story, germs of novella within the 
novella (...) episodes drifted into narration" (Bence 2008, 75), "low-Pannonian fragments" (Tolnai 2011 (2007)), small forms, novel of fragments, in which "the emphasis is on the process of creation" (Bence 2008, 76).

Beáta Thomka speaks about poetic prose, whose structural units are diverse, still uniform: "collage narration," "patchwork narrative," "moment mosaics, filings, splinters," "moment-prose" (Thomka 1994). The source of poetic character is fragmentation, the light and fast flow of the text, one great version of which is the "stained water prose." Tolnai's efforts in this direction are already formulated (indirectly) in the motto of the novel entitled Flower Street 3 [Virág utca 3]:

My literary work consists exclusively of including such notes and fragments (literally) into my work that I have already written down in connection with everything in the world, at every stage of my narrative. Elaborating a topic means to me grouping the already existing details around a later selected or suggested topic. I accept nothing else as material, only details given by the circumstances that come naturally, if they come, and are worth as much as they are. For me, the topic is as irrelevant to the literary work as the text of an opera-that the listener usually does not understand-and that is anyway just a mere indication. (Valéry Papers) (Tolnai 2010 (1983), 5)

Due to the results of the above methods, in Tolnai's texts

[...] the different genres almost dissolve, become one in the personal tone; with him the motifs are connected to each other more tightly than with other writers; the cohesion created by the motifs of the writings is almost stronger than the unity created by the order of the particular writings. It is not the writings that create the writer's world, but vice versa, it is the writer's world that creates [...] the writings. (Füzi 1997, 1253)

The text generating, "text rolling operations" of the Tolnai opus are briefly described by Éva Hózsa in the way the elements of the work of art "are rearranged, they drip into each other" (according to the model of sandcastle building) (Hózsa 2012, 35).

\section{Meeting of cultures, intercultural passages}

Tolnai's fragment collages and hypertexts are reconstructions, continuous recreations of various cultures and relation systems. The various text forming procedures create the contacts and intercultural passages of the particular texts through the application of metaphors. 
“The literary work is a transcendent and burly spider web” (Parti Nagy 2004, 11). “Encyclopaedia or spider web?” Lajos Kántor asks in the wake of Lajos Parti Nagy. Our answer is: spider web and encyclopaedia. The spider web is the encyclopaedia itself. The ancestor of the hypertext, the genre including the totality of human knowledge makes the relating system, built like a spider web, complete, of documentary value, representative, and dynamic. "Ottó Tolnai is an excellent spectator-contemplator, a great receiver and preserverthough he is as much an innovator as well" (Kántor 2005, 75). His opus is like the continuously changing extended editions of a big encyclopaedia. The complex texture of the Tolnai type encyclopaedia supports the wide horizon, the transcendent arch of the encyclopaedia (Bence 2008); the corpus made of narrators, stories, heroes, and objects, permeated by domestic and private mythology, is "the breviary, encyclopaedia, literary anthology of the Pannonian micro-region fate stories-the imprint of world understanding in novel form and the mythical story of novel writing at the same time" (Bence 2008, 79). The "void” (Füzi 1997) 'entries' of the New Tolnai Encyclopaedia rethink and poeticize the genre of the encyclopaedia.

The sea is the most important "subject" of the encyclopaedia. Tolnai is the encyclopaedist of the azure, of "the sea attracting and absorbing everything into itself" (Virág 2003, 116). Tolnai’s stained water is "the territory of multiracialism and manifoldness, of the situatedness within and beyond, of the finite and infinite, life and death, the visible and the invisible" (Virág 2003, 116).

In the field of association of the sea penetrating everywhere there appear the delta and the delta situation. The delta is the meeting point of the starting point and end point, it is rise and estuary, a collecting area and mixing surface, an imaginary region (quite like Vojvodina) "that is the permeable, receptive, and containing medium of cultural and intellectual values and currents. It is a virtual gate standing at the crossroads of cultures, cardinal points, and civilisations. There were times when free flow might have circulated through this to Central Europe, between the Balkans and the Mediterranean" (Thomka 2007, 11-12). The delta situation is the positionedness of multiple-rooted identity, of the multilingual and multicultural Homo Adriaticus. It implies a border situation that simultaneously brings an end and recreates, separates and binds, "it is the reservoir of the existence oscillating between the Self and The Other, the familiar and the foreign, the small and the big, source and destination, periphery and centre, marginality-minority and dominance” (Csányi 2007, 53).

The cultural figurations of the river, the delta and the sea appear to be in a border situation themselves, in the flow of Hungarian literature. In connection with the layers of the Hungarian literary tradition, Tolnai's hydrographic map overwrites Ferenc Herczeg's sea view, and last but not least, connects to the love-geography, to "the standard elements of emotional cartography." On the other hand, they can 
also be interpreted as the cultural (artistic, literary, culture-historical and private) atlas of the symposionist art of writing (Virág 2010, 8).

The reservoir of the delta can be brought into connection with the relics treasured in the early museums, with the heterogeneity of the chaotic objectual world. The prototype, the source of the museum experience of the Tolnai opus is the father's, Mátyás Tolnai’s shop in Stara Kanjiža, "registered in certain texts sometimes as a grocery, sometimes as a shop of colonial goods" (Mikola 2005, 76). The narrator's affinity tending towards collections is developed further by the stock of the Novi Sad Store of the Yugoslav times. "Graceful trifles! Graceful tastes!” cause the narrator's delight (Tolnai 2010 (1987), 121).

The sacral private collection of Homokvár in Palić, appearing much later, is connected to this objectual world. The above context is supported by the narrator's self-characterization, according to which the storyteller stuck into the space of the attic is the "guard of trifles" (Tolnai 2012 (1972), 62). His alter ego, Mária Róza Bánszky, restorer of the Museum of Novi Sad (Vojvodina), about whom we can only know that "her name often appears in my writings, in many of my stories and poems actually being nothing else, but her words taken down" (Tolnai 2011 (2007), 314). The collection, the maniacal archiving of authentic and false references are both the topic and the text organizing procedure of Tolnai's prose (Novák 2012).

In the Tolnai type text universe or "text cathedral" (Rudas 2010, 41) the trifles endlessly enlarge the circle of the "objects" that can be archived in the museum space. There is room for everything here: adventure, experience, mystery, mood, colours, scrolls, connections, passages—an imaginary "collection resulting from a creative process,” a "text museum” (Novák 2013, 35).

\section{Encounter of cultures-the narrator's "self- reinterpretations" (Vitéz 1997)}

The process of (text) writing creates the one-ness, the essence of which, in Valéry's interpretation, is not the harmony, but the "awareness of the transitions from construction to destruction, from destruction again to construction through writing and thinking” (Vitéz 1997, 5). Tolnai's narrators, alter egos, speaking from various (minor and intermediary) (speech) situations, synthesize the world view of the continuously forming textual universe of Tolnai's with epithets such as Yugoslavian, Vojvodinean, from Novi Sad, from Bačka, from Stara Kanjiža.

The passages, inherent in spaces and revealed in the course of space shifts, between majority and minority, national and multicultural, central and peripheral cultures generate a heterogeneous textual universe, wherein "the literary representations create an illusion of knowledge and identity with the 
territories referenced. The readers share the description of these spaces and mentally assimilate the geography" (Alves-Queiroz 2013, 459). The narrator of Tolnai's complex text is active, his entity coming to life in the process of the reader's (identity) forming process. Tolnai's narrator codes the culture-historical traditions constructing Tolnai's textual spaces, reshaped again and again in space and time, and stores them for the (identity) decoding reader of all times.

\section{Editions}

Tolnai Ottó. 1992. Oláh Sándor újvidéki tárlata. [Sándor Oláh’s Exhibition in Novi Sad.] In A meztelen bohóc. Képzómúvészeti esszék [The Naked Clown. Essays on Fine Arts], 12-18. Novi Sad: Forum.

—. 1994. Költó disznózsírból. Egy rádióinterjú regénye. [Poet from Lard. Novel of a Radio Interview.] Interviewer: Lajos Parti Nagy. Bratislava: Kalligram.

—. 2010 (1983). Virág utca 3. [Flower Street 3.] Budapest: Petőfi Irodalmi Múzeum. (Source edition: Novi Sad: Forum, 1983.) http://dia.jadox.pim.hu/jetspeed/displayXhtml?offset=1\&origOffset=-1\&docI $d=317 \&$ secId=29807\&limit=10\&pageSet=1. (Accessed on 3 February 2014)

—. 2010 (1987). Ló az Újvidéki Áruházban. [A Horse in the Department Store in Novi Sad.] In Prózák könyve [Book of Prose]. Budapest: Petőfi Irodalmi Múzeum. (Source edition: Novi Sad: Forum, 1987.)

http://dia.jadox.pim.hu/jetspeed/displayXhtml?offset=1\&origOffset=-1\&docI $d=1124 \&$ secId=111338\&limit=10\&pageSet=1 (Accessed on 23 January 2014)

—. 2010 (1992). árvacsáth. [orphancsáth.] Budapest: Petőfi Irodalmi Múzeum. (Source edition: Budapest, Novi Sad: Orpheusz, Forum, 1992.)

http://dia.jadox.pim.hu/jetspeed/displayXhtml?offset=1\&origOffset=-1\&docI $d=396 \&$ secId=35212\&limit=10\&pageSet=1 (Accessed on 20 January 2014)

—. 2010 (1997). Rothadt márvány. Jugoplasztika. [Rotten Marble. Yugoplastics.] Budapest: Petőfi Irodalmi Múzeum. (Source edition: Budapest: Kijárat)

—. 2010. Világítótorony eladó. Festettvíz-próza. [Lighthouse for Sale. Stained Water Prose.] Zenta: zEtna, Basiliscus.

—. 2011 (2007). A pompeji szerelmesek. Fejezetek az Infaustusból. [Lovers of Pompeii. Chapters from the Infaustus.] Budapest: Petőfi Irodalmi Múzeum. (Source edition: Pécs: Alexandra, 2007.) http://dia.jadox.pim.hu/jetspeed/displayXhtml?offset=1\&origOffset=-1\&docI $d=7811 \&$ secId=819601\&limit=10\&pageSet=1 (Accessed on 21 January 2014)

—. 2011 (2008). Grenadírmars. - egy kis ízlelt opus -. [Grenadírmars. - a tasted opus -.] Budapest: Petőfi Irodalmi Múzeum. (Source edition: Zenta: zEtna, 2008.)

—. 2012. (1972). Gogol halála. [Gogol's Death.] Budapest: Petőfi Irodalmi Múzeum. (Source edition: Novi Sad: Forum, 1972.) 
http://dia.jadox.pim.hu/jetspeed/displayXhtml?offset=1\&origOffset=-1\&docI $d=8018 \&$ secId $=843506 \&$ limit=10\&pageSet $=1$ (Accessed on 10 February 2014)

\section{Works cited}

Acsai Roland. 2004. „Minden beőröltetett”. [“Everything has crumbled”.] In Tolnai-Symposion: Tanulmányok Tolnai Ottó múveiról [Tolnai Symosion: Studies on Ottó Tolnai's writings], ed. Beáta Thomka, 107-110. Budapest: Kijárat.

Alves, Daniel-Queiroz, Ana Isabel. 2013. Studying Urban Space and Literary Representations Using GIS. Lisbon, Portugal, 1852-2009. Social Science History, vol. 37. no. 4 (Fall): 457-481.

Bence Erika. 2008. Tolnai-tárgylexikon: Tolnai Ottó: A pompeji szerelmesek. [Tolnai Encyclopaedia: Ottó Tolnai: Lovers of Pompeii.] Híd, vol. 56 no. 2 (Fall): 75-79.

Csányi Erzsébet. 2007. Vajdaság: az átalakulás tégelye: Kulturális kódok deltája Tolnai Ottó prózájában. [Vojvodina: Melting Pot of Transformation: The Delta of Cultural Codes in Ottó Tolnai's Prose.] In konTextus, ed. Erzsébet Csányi, 51-58. Novi Sad: Bölcsészettudományi Kar, Vajdasági Magyar Felsőoktatási Kollégium.

Daniel, Jean. 1996. A mediterráneumról. [About the Mediterranean.] Lettre, vol. 2 no. 21 http://epa.oszk.hu/00000/00012/00005/10dan.htm (Accessed on 2 March 2014)

Füzi László. 1997. Kis „semmisek” az Új Tolnai Lexikonból: Tolnai Ottó: Rothadt márvány (Jugoplasztika). [Little "voids" from the New Tolnai Lexicon: Rotten Marble. (Yugoplastics)]. Jelenkor, vol. 15 no. 12 (Fall): 1253-1255.

Hózsa Éva. 2012. Homokvár-csöpögtető ujjak: Az Ördögfej és a Tolnai-opus szöveggörgető múveletei. [Sandcastle-Dropping Fingers: Text Scroll Actions in Devil's Head and the Tolnai Opus.] Habitus, ed. Erzsébet Csányi, 21-37. Novi Sad: Bölcsészettudományi Kar, Vajdasági Magyar Felsőoktatási Kollégium.

Kántor Lajos. 2005. Tolnai Ottó glóbusza - enciklopédia vagy pókháló? [Ottó Tolnai's Globe - Encyclopaedia or Spider Web?] Korunk, vol. 16 no. 6 (Fall): $73-76$.

Ladányi István. 2004. Az Adria Tolnai Ottó költészetében, különös tekintettel a Balkáni babérra. [The Adriatic in Ottó Tolnai’s Poetry, with Special Regard to the Balkan glory.] In Tolnai-Symposion: Tanulmányok Tolnai Ottó múveiról [Tolnai-Symposion: Studies on Ottó Tolnai's writings], ed. Beáta Thomka, 4751. Budapest, Kijárat.

Mikola Gyöngyi. 2005. A Nagy Konstelláció. [The Big Constellation.] Pécs: Alexandra. 
—. 2012. A Symposion képi fordulata. [Pictorial turn of the Symposion] In Médiumok, történetek, használatok - Ünnepi tanulmánykötet a 60 éves Szajbély Mihály tiszteletére, [Media, Stories, Applications - Festive Volume of Essays and Studies in Honour of the 60- Year-Old Mihály Szajbély], ed. Bertalan Pusztai, 411-420. Szeged: Szegedi Tudományegyetem Kommunikáció- és Médiatudományi Tanszéke.

Novák Anikó. 2012. A szemétdombtól a képzeletbeli múzeumig: Gyűjtőszenvedély Tolnai Ottó múveiben. [From Dunghill to an Imaginary Museum: Mania for Collecting in Ottó Tolnai's writings.] In Habitus, ed. Erzsébet Csányi, 39-47. Novi Sad: Bölcsészettudományi Kar, Vajdasági Magyar Felsőoktatási Kollégium. —. 2013. Érzelmes utazások a múzeumban. [Emotional Journeys in the Museum.] In Utazás - megértés - identitás [Journey - Understanding - Identity], ed. Erzsébet Csányi, 31-39. Novi Sad: Bölcsészettudományi Kar, Vajdasági Magyar Felsőoktatási Kollégium.

Reuschel, Anne-Kathrin-Hurni, Lorenz. 2011. Mapping Literature: Visualisation of Spatial Uncertanity in Fiction. The Cartographic Journal, vol. 48. no 4 (Fall): 293-308. http://www.literaturatlas.eu/files/2012/02/Reuschel2011_CAJ.pdf (Accessed on 2 August 2014)

Rudas Jutka. 2010. Ki építi a homokvárat? Tolnai Ottó infaustusairól. [Who Builds the Sandcastle? About Ottó Tolnai’s Infaustus.] In Alteregó. Alakmások - hamismások - heteronimák [Alter Ego. Masks - Alter Egos - Heteronyms], ed. Erzsébet Csányi, 37-46. Novi Sad: Bölcsészettudományi Kar, Vajdasági Magyar Felsőoktatási Kollégium.

—. 2012. A Disznózsírt olvasva. [On reading "Disznózsír”.] In Rudas Jutka: Kulturális intarziák = Kulturne intarzije. Válogatott írások = Izabrani spisi [Cultural inlays = Kulturne intarzije. ], 62-68. Pilisvörösvár: Muravidék Baráti Kör Kulturális Egyesület.

Thomka Beáta. 1986. A pillanat formái. A rövidtörténet szerkezete és múfaja. [Forms of the Moment: Generic and Structural Issues of the Short Story.] Novi Sad: Forum.

—. 1994. Tolnai Ottó. [Ottó Tolnai.] Bratislava: Kalligram.

—. 2007. Egy Tolnai-metafora visszavezetése: A delta lehetséges poétikai redukciója. [A Possible Poetical Reduction of the Tolnai Metaphor, the Delta.] In konTEXTUS: Összehasonlító irodalomtudományi tanulmányok [conTEXT: Studies on Comparative Literature], ed. Erzsébet Csányi, 7-14. Novi Sad: Vajdasági Magyar Felsőoktatási Kollégium. http://dda.vmmi.org/docs_ szabadpolc/b_kontextus.pdf (Accessed on 1 March 2014)

Virág Zoltán. 2003. Az azúr enciklopédistája: Tolnai Ottó írásmúvészetéról. [Encyclopaedist of the Azure: About Ottó Tolnai's Art of Writing] Forrás, vol. 35 no. 11 (Fall): 114-118. 
—. 2010. Az élmények koloritja. A folyó, a delta és a tenger kulturális alakzatai a symposionista költészetben és prózában. [Colours of Experiences. Cultural Figures of the River, the Delta and the Sea in the Symposionist Poetry and Prose.] Forrás, vol. 42 no. 6 (Fall): 6-14. http://www.forrasfolyoirat.hu/ (20 February 2014)

Vitéz Ferenc 1997. Táncoló nő az élet. A zene és az építészet helye és kapcsolata Paul Valéry énkereső módszerében. [Life is a Dancing Woman. The State and Connection of Music and Architecture in Valéry Paul's Self-Seeker Method.] Alföld, vol. 58 no. 12 (Fall): 1-11. http://epa.oszk.hu/00000/00002/00024/vitez.html (Accessed on 2 March 2014) 